\title{
Comparison of functional outcomes in patients fixed with dynamic hip screw and proximal femur nail-anti-rotation in $\mathrm{A} 1$ and $\mathrm{A} 2$ type intertrochanteric femur fractures
}

\author{
Hüseyin Fatih Sevinç, M.D., ${ }^{1}$ () Meriç Çırpar, M.D., ${ }^{2}$ () İbrahim Deniz Canbeyli, M.D., ${ }^{2}$ \\ Bülent Dağlar, M.D., ${ }^{3}$ () Birhan Oktaş, M.D., ${ }^{\circledR}$ Serhat Durusoy, M.D. ${ }^{4}$
}

\author{
1'Department of Orthopedics and Traumatology, Nevşehir State Hospital, Nevşehir-Turkey \\ ${ }^{2}$ Department of Orthopedics and Traumatology, Kırıkkale University Faculty of Medicine, Kırıkkale-Turkey \\ ${ }^{3}$ Department of Orthopedics and Traumatology, Güven Hospital, Ankara-Turkey \\ ${ }^{4}$ Department of Orthopedics and Traumatology, Bozok University Faculty of Medicine, Yozgat-Turkey
}

\begin{abstract}
BACKGROUND: We aimed to compare clinical and functional outcomes between patients treated with Dynamic hip screw (DHS) and Proximal Femoral Nail-Antirotation (PFN-A) implants.

METHODS: This study included 122 patients (66 men [54.1\%] and 56 women [45.9\%]) who underwent surgery with DHS and PFN-A for an intertrochanteric femur fracture and had at least 12 months follow-up. Reduction assessment, femoral neck-shaft angle and tip-apex distance measurements were performed in early postoperative radiographs. On control visits in months I, 3, 6 and I2, range of motion, thigh or hip pain, and Trendelenburg positivity were assessed in clinical examination and reduction assessment, femoral neck-shaft angle and tip-apex distance measurements were performed on radiographs after the union. Patients were assessed using Hip Harris Score after the union.
\end{abstract}

RESULTS: Regardless of implant type used, mean tip-apex distance measured at the immediate postoperative period was 27.6 in patients with implant failure, whereas 21.6 in patients without, indicating a significant difference. Again, mean femoral neck-shaft angle measured at the immediate postoperative period was 123 degree in patients with implant failure, whereas 130 degree in those without, indicating a significant difference. It was found that the femoral neck-shaft angle was $<128$ degree in all patients with implant failure whereas it was $>128$ degree in $94 \%$ of patients without implant failure at immediate postoperative period.

CONCLUSION: The findings regarding femur neck-shaft angle at the immediate postoperative period was $<128$ degree in all patients with implant failure and that it was $\geq 128$ degree in $94 \%$ of patients without implant failure emphasize the importance of anatomic restoration in femur neck-shaft angle during surgery. The finding that mean tip-apex distance was $27.6 \mathrm{~mm}$ in patients with implant failure and $21.6 \mathrm{~mm}$ in patients without implant failure indicates that the technique is as important as implant type selected for treatment success of the implantation.

Keywords: Dynamic hip screw; femoral neck-shaft angle; intertrochanteric femur fractures; proximal femoral nail anti-rotation; tip-apex distance.

\section{INTRODUCTION}

In the treatment of intertrochanteric femur fractures, which often occur in elder individuals, the aim is to return to daily activities as before the fracture and to prevent complications that arise from immobilization by ensuring mobilization as soon as possible. ${ }^{[1]}$ There is a consensus that the primary aim is to ensure early mobilization by providing stable fixation. ${ }^{[2]}$

\footnotetext{
Cite this article as: Sevinç HF, Çırpar M, Canbeyli İB, Dağlar B, Oktaş B, Durusoy S. Comparison of functional outcomes in patients fixed with dynamic hip screw and proximal femur nail-anti-rotation in A1 and A2 type intertrochanteric femur fractures. Ulus Travma Acil Cerrahi Derg 2020;26:811-817.

Address for correspondence: Hüseyin Fatih Sevinç, M.D.

Nevşehir Devlet Hastanesi, Ortopedi ve Travmatoloji Kliniği, Nevşehir, Turkey

Tel: +90 384 - 2285050 E-mail: drhfatihsevinc@gmail.com

Ulus Travma Acil Cerrahi Derg 2020;26(5):8II-8I7 DOI: 10.14744/tjtes.2020.39888 Submitted: 0I.II.2019 Accepted: 02.02.2020 Online: 09.09.2020 Copyright 2020 Turkish Association of Trauma and Emergency Surgery
} 
However, there is an ongoing debate on the selection of the implant type to be used for fixation.

Dynamic hip screw (DHS) is considered as the gold standard in the treatment of stable intertrochanteric femur fractures. [3,4] The rate of implant problems is $1 \%$ in stable intertrochanteric femur fractures, whereas the rate reaches up to $20 \%$ in unstable intertrochanteric femur fractures treated by DHS. [5,6] Despite the success of lag plate-screw implants, failure in unstable fractures has led to an increased interest in proximal femur nails (PFN). ${ }^{[7]}$ Theoretically, PFNs have many biomechanical advantages when compared to lag screws. Despite their advantages, their rate of complications is higher than lag screws. ${ }^{[8]}$ There are new-generation nails designed to reduce complication rates. As a result, PFNs are increasingly used in the treatment of both stable and unstable intertrochanteric femur fractures. In a study conducted by Anglen and Weinstein, it was found that the rate of PFN use reached from $3 \%$ in 1999 to $67 \%$ in $2006 .{ }^{[9]}$ However, many studies showed that there was no significant difference between DHS and PFN-antirotation (PFN-A) used in the treatment of low-energy ( $\mathrm{AI}$ and $A 2$ ) intertrochanteric fractures concerning radiological and clinical parameters, operation time, scopy time, mean blood loss, length of hospital stay and functional outcomes. [4,10-12] In several series, excellent outcomes were achieved with DHS used for fixation in intertrochanteric fracture. ${ }^{[13,14]}$

In this study, we aimed to compare clinical and functional outcomes between patients treated with DHS and PFN-A implants. This study was approved by the Institutional Ethics Committee numbered 04/01-23.02.1015. All patients gave written informed consent before their participation.

\section{MATERIALS AND METHODS}

This study included 122 patients (66 men [54.1\%] and 56 women [45.9\%]) who underwent surgery with DHS and
PFN-A for an intertrochanteric femur fracture and had at least 12 months follow-up. Patients who had undergone surgery with a proximal femoral plate and bipolar hip arthroplasty for intertrochanteric fracture of the femur and patients who did not voluntarily participate in follow-ups and did not willingly participate in this study were excluded. As the use of DHS in the treatment of $A 3$ type femur intertrochanteric fractures resulted in high complication rates, A3 type fractures were excluded from this study. This study was conducted in the outpatient setting at a tertiary-level care center in three surgeons' practice (Figs. I, 2).

Bilateral anteroposterior and lateral hip radiographs, anteroposterior femur radiographs including the hip on the involved side, and hip radiographs in internal rotation were taken at presentation for all patients. Fractures were classified according to the Müller AO classification system.

Patients were operated on by three surgeons who had 10 years of experience as a specialist in orthopaedics and traumatology. Implant selection was made according to our clinical protocol, which considered fracture and patients' characteristics. No randomization was used for implant selection. All patients were treated on the elective basis as soon as conditions are satisfied. Radiolucent standard operating table was used according to surgeons' preference. All patients were positioned supine with a bump under the ipsilateral buttock when the standard table was used. Perfect anteroposterior and lateral images were obtained before patient preparation. Standard operative techniques were utilized according to implant chosen. The postoperative regime was the same for all patients, which includes immediate weight-bearing according to patients' tolerance.

Reduction assessment, femoral neck-shaft angle and tip-apex distance measurements were performed in early postoperative radiographs. On control visits in months I, 3, 6 and 12, range of motion, thigh or hip pain and Trendelenburg positivity
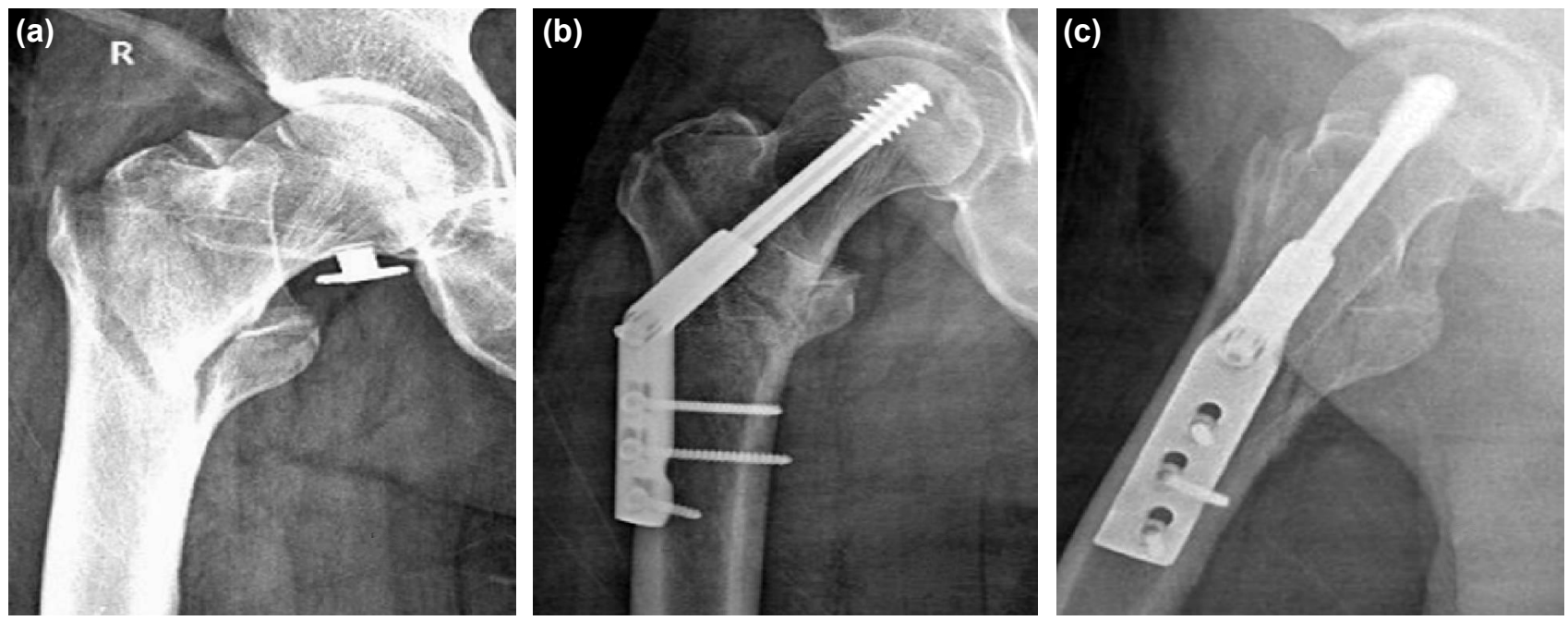

Figure 1. (a) Anteroposterior radiograph of a 56 years old man with an A1 type intertrochanteric femur fracture. (b) Postoperative anteroposterior radiograph of the fracture treated with DHS. (c) Postoperative lateral radiograph of the fracture treated with $\mathrm{DHS}$. 

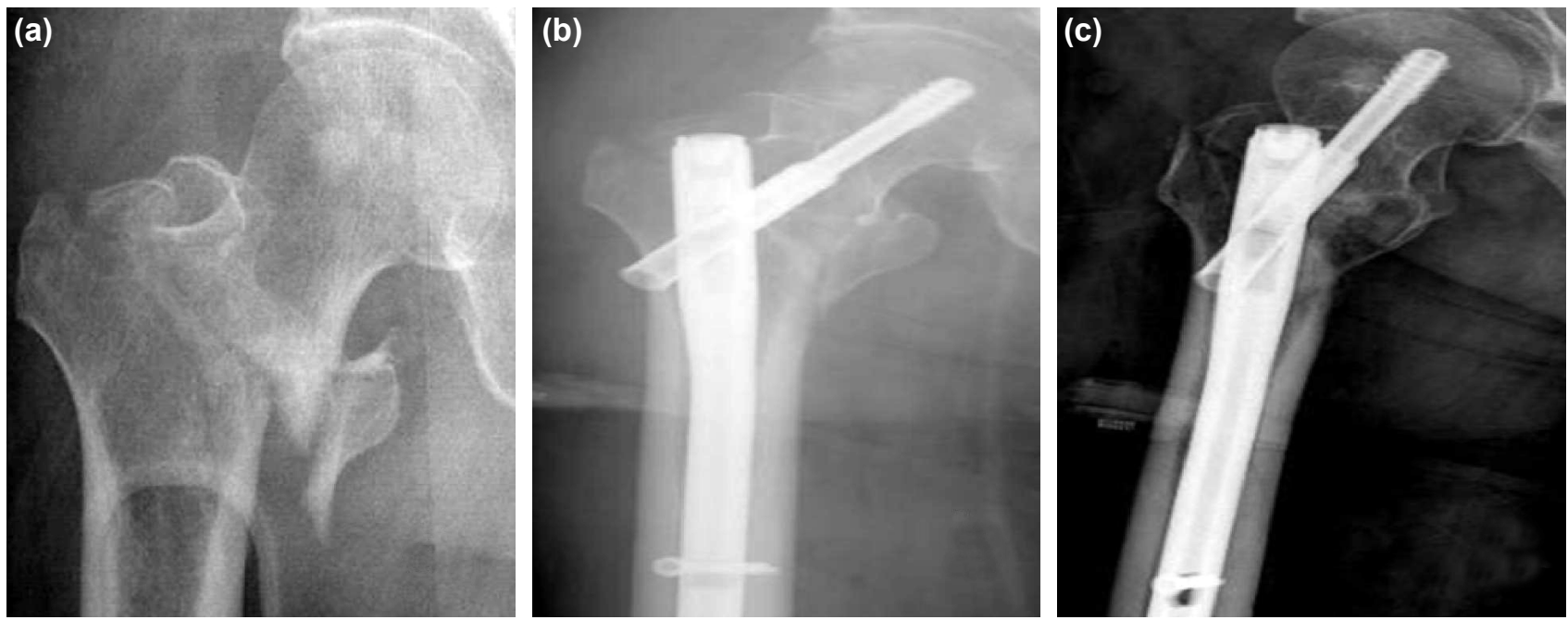

Figure 2. (a) Anteroposterior radiograph of an 83 years old man with an A2 type intertrochanteric femur fracture. (b) Postoperative anteroposterior radiograph of the fracture treated with PFN-A. (c) Postoperative lateral radiograph of the fracture treated with PFN-A.

were assessed in clinical examination and reduction assessment, femoral neck-shaft angle and tip-apex distance measurements were performed on radiographs after the union. Patients were assessed using Hip Harris Score after the union.

Statistical analyses were carried out using the SPSS version 17.0 software package. Descriptive statistics (mean, standard deviation) were used to analyze the data. Quantitative data with normal distribution were compared using Student's t-test, and those with skewed distribution were compared using the Mann-Whitney $U$ test. To assess relationships, Pearson's correlation analysis was used for parametric variables and Spearman's correlation analysis was used for non-parametric variables.

\section{RESULTS}

When the mechanism of injury was considered, it was found that fractures developed as a result of fall at home in 109 (89.3\%), fall at outdoors in eight $(6.6 \%)$, in-vehicle traffic accident in three $(2.5 \%)$ and out-of-vehicle traffic accident in two patients (1.6\%). No significant difference was detected concerning implant type according to the mechanism of injury $(p=0.370)$.

Patient characteristics in the DHS and PFN-A groups are shown in Table I. Patient characteristics in the both Al groups are shown in Table 2. Patient characteristics in the both A2 groups are shown in Table 3 .

Table I. Patients characteristics in both groups

\begin{tabular}{lccc}
\hline Variable & DHS (n=66) & PFNA (n=56) & p \\
\hline Age (years) & $77.1(35-92)$ & $78.9(50-105)$ & 0.370 \\
Sex (male/female) & $39 / 27$ & $27 / 29$ & 0.230 \\
AO, $n$ (\%) & & & 0.00 I \\
$\quad$ AI & $48(72.7)$ & $16(28.6)$ & \\
$\quad$ A2 & $18(27.3)$ & $40(71.4)$ & \\
Side (right/left) & $39 / 27$ & $27 / 29$ & 0.986 \\
Singh Index & 2.81 & 2.78 & 0.755 \\
Implant failure (n=13) (I0.7\%), (\%) & $2(3.0)$ & $11(19.6)$ & 0.003 \\
Mean TAD immediate postoperative & 21.3 & 23.5 & 0.009 \\
Mean TAD after the union & 20.4 & 18.9 & 0.281 \\
Mean NSA immediate postoperative & 132.2 & 126.2 & 0.001 \\
Mean NSA after the union & 130 & 124 & 0.001 \\
Harris & 80.5 & 66.5 & 0.001 \\
Trendelenburg, n (\%) & $4(6.1)$ & $25(44.6)$ & 0.001 \\
\hline
\end{tabular}

DHS: Dynamic hip screw; PFNA: Proximal femoral nail-antirotation; TAD: Tip apex distance; NSA: Neck shaft angle. 
Table 2. Patients characteristics in both Al groups

\begin{tabular}{lccc}
\hline Variable & DHS $(\mathbf{n}=\mathbf{6 6})$ & PFNA $(\mathbf{n = 1 6})$ & $\mathbf{p}$ \\
\hline Implant failure $(\mathrm{n}=2)(3.1 \%)$ & 0 & $2(12.5 \%)$ & 0.013 \\
Mean TAD immediate postoperative & 20.9 & 22.1 & 0.377 \\
Mean TAD after the union & 20.5 & 19.5 & 0.281 \\
Mean NCA immediate postoperative & 132.5 & 127.7 & 0.001 \\
Mean NSA after the union & 130.8 & 126 & 0.001 \\
Harris & 84 & 72.5 & 0.004 \\
Trendelenburg & $2(4.2 \%)$ & $5(31.3 \%)$ & 0.003 \\
\hline
\end{tabular}

DHS: Dynamic hip screw; PFNA: Proximal femoral nail-antirotation; TAD: Tip apex distance; NSA: Neck shaft angle.

Table 3. Patients characteristics in both $A 2$ groups

\begin{tabular}{lccc}
\hline Variable & DHS $(\mathbf{n}=18)$ & PFNA $(\mathbf{n}=\mathbf{4 0})$ & $\mathbf{p}$ \\
\hline Implant failure $(\mathrm{n}=\mathrm{II})(19 \%)$ & $2(11.1 \%)$ & $9(22.5 \%)$ & 0.306 \\
Mean TAD immediate postoperative & 22.1 & 24 & 0.138 \\
Mean TAD after the union & 20.1 & 18.7 & 0.566 \\
Mean NCA immediate postoperative & 131.3 & 125.7 & 0.001 \\
Mean NSA after the union & 127.7 & 123.2 & 0.016 \\
Harris & 71.1 & 64.2 & 0.270 \\
Trendelenburg & $2(I I .1 \%)$ & $20(50 \%)$ & 0.005 \\
\hline DHS: Dynamic hip screw; PFNA: Proximal femoral nail-antirotation; TAD: Tip apex distance; NSA: Neck shaft angle.
\end{tabular}

When early mobilization was assessed, 66 patients (100\%) treated with DHS were mobilized at the first postoperative day by weight-bearing as tolerated, while $5 \mathrm{I}(91.1 \%)$ treated with PFN-A were mobilized at the first postoperative day by weight-bearing as tolerated. Four patients $(7.1 \%)$ were mobilized by partial weight-bearing, and no weight-bearing was allowed in one patient (1.8\%). A significant difference was detected between the groups concerning the postoperative first day early mobilization $(p=0.046)$.

When complications were considered, complications were observed in eight patients who underwent DHS (12.1\%) and in $12(21.4 \%)$ who underwent PFN-A, indicating a significant difference $(p=0.065)$.

In DHS patients, complications included a loosening of compression screw in six patients and implant failure in two patients. In PFN-A patients, complications included intraoperative fracture in one patient and implant failure in $\mathrm{II}$.

Regardless of the implant type, mean tip-apex distance measured at the immediate postoperative period was 27.6 in patients with implant failure and 21.6 in patients without, indicating a significant difference $(p=0.001)$. Again, mean femoral neck-shaft angle measured at the immediate postoperative period was 123 degrees in patients with implant failure and
130 degrees in those without, indicating a significant difference $(p=0.00 \mathrm{l})$. It was found that the femoral neck-shaft angle was $<128$ degrees in all patients with implant failure and $>128$ degrees in $94 \%$ of patients without implant failure at the immediate postoperative period.

\section{DISCUSSION}

DHS is the choice of the implant in stable fractures, while the intramedullary nail is preferred in instable fractures due to its effectiveness. However, there is no consensus on the choice of the implant in unstable fractures. ${ }^{[15]}$ We should note that given that DHS systems are inadequate for instable fractures, there is a growing interest in intramedullary nails. While DHS is the choice of the implant in stable fractures, the preference of surgeons has shifted to PFN-A due to its potential biomechanical advantages in theory. ${ }^{[15]}$ In a multicenter meta-analysis, including 3279 patients, it was concluded that intramedullary nails had no superiority over the dynamic hip screw in both stable and instable trochanteric fractures. ${ }^{[6]}$ In many studies, dynamic hip screws have been considered as the gold standard in the treatment of stable intertrochanteric femur fractures. ${ }^{[8,15,17]}$ When our cases were assessed according to the Müller AO classification, it was seen that we mainly used DHS in $A$ I fractures and PFN-A in A2 fractures. 
At the immediate postoperative period, a significant difference was detected between patients with and without implant failure regarding femoral neck-shaft angle, which is used to investigate whether the reduction is achieved in varus-valgus position in clinical practice. The finding that the femur neck-shaft angle at the immediate postoperative period was $<128$ degrees in all patients with implant failure, and that it was $\geq 128$ degrees in $94 \%$ of those without implant failure emphasizes the importance of anatomic restoration in femur neck-shaft angle during surgery. These data are inconsistent with the study of Davis et al., ${ }^{[18]}$ who reported that the femur-shaft angle did not affect the loosening rate. Şahin et al. ${ }^{[19]}$ found the mean femur-shaft angle as 136.7 degrees in patients treated for instable intertrochanteric femur fracture, and authors observed that femur-shaft angle decreased from 125 degrees to 118 in a case with the loosening of the helical screw. In a study by Ertürer et al., ${ }^{[20]}$ the mean femur-shaft angle was found to be 125.5 degrees in patients treated with profine nail for the intertrochanteric femur fracture. The femur-shaft angle is approximately 125 degrees in individuals aged $>75$ years. ${ }^{[2]}$ Based on our data, we think that femur-shaft angle $<128$ degrees is not acceptable at the immediate postoperative period as it increases complications.

Lag screws are used for fixation in DHS and PFN-A fixation systems for intertrochanteric femur fractures, which is sent to the femur head via femur neck over the implant system. The tip-apex distance is the best marker for implant survival and outcome, which was first defined by Baumgaertner et al. ${ }^{[5,22]}$ Tip-apex distance is directly correlated to implant failure. Baumgaertner et al. ${ }^{[5,22]}$ suggested that implant failure is less likely when the tip-apex distance is below $25 \mathrm{~mm}$ and that it is the most important parameter, although not the only one, to predict treatment success. In our study, regardless of implant type, a significant difference was detected between patients with and without implant failure in terms of immediate postoperative tip-apex distance. In consistent with the literature, the finding that mean tip-apex distance was $27.6 \mathrm{~mm}$ in patients with implant failure and $21.6 \mathrm{~mm}$ in those without indicates that the technique is as important as implant type for the success of implantation.

In A2 fractures, no significant difference was found in tip-apex distance measured at the immediate postoperative period and after the union between DHS and PFN-A groups. However, the presence of a significant difference in femur-shaft angel favoring DHS at immediate postoperative period and after the union and better clinical outcomes in DHS patients indicates that the DHS system can maintain long-term stability even in displaced fractures.

When clinical outcomes and complications were assessed in our study, complication rates for $A 1$ and $A 2$ fractures were lower in the DHS group when compared to the PFN-A group, and complications were considered as minor in the
DHS group. When the groups were compared regarding Hip Harris Score, it was found that Hip Harris Score was higher in A2 fractures undergoing DHS. We think that the difference occurred as PFN-A was mainly preferred in A2 fractures, in which stable reduction can be challenging. In many studies comparing DHS and gamma nail, it was shown that there was no significant difference in terms of complications and clinical and functional outcomes. ${ }^{[23-27]}$ However, $\mathrm{Xu}$ et al. ${ }^{[28]}$ reported that PFN-A was associated with lower complication rates than DHS. Again, Kristek et al. ${ }^{[29]}$ reported lower complications in patients undergoing PFN-A. Thus, these advantages in the selection of the implant system can explain the tendency to choose intramedullary nails. In the literature, there are studies reporting that walking ability at the postoperative period was recovered more rapidly with intramedullary nails when compared to DHS and that intramedullary nails provided better restoration of hip anatomy. In our study, the finding of less Trendelenburg and significantly higher Hip Harris Score in DHS patients is inconsistent with the literature. In many studies, it was reported that walking ability was recovered more rapidly in PFN-A patients than DHS patients. ${ }^{[29,30]}$ Another difference in our study was the finding that DHS patients could be mobilized earlier with weight-bearing as tolerated. We think that the differences in recovery of walking ability, presence of Trendelenburg and tolerance to weight-bearing can be attributed to injury in the hip abductor mechanism for optimal positioning of the intramedullary nail.

In conclusion, based on our findings, we think that fracture type and stability, and regardless of the system used, tip-apex distance are the most important factors in the selection of the implant system for fixation. We believe that DHS when implemented by a proper technique, will provide better results in $\mathrm{Al}$ and $\mathrm{A} 2$ fractures (if a stable reduction is possible) regarding union, functional outcomes and complication rates. However, further studies with larger samples are needed to use these findings as a guide in clinical practice.

\section{Conclusion}

We think that both DHS and PFN-A implant systems can be selected in $\mathrm{Al}$ intertrochanteric femur fractures and that both systems can ensure union without implant failure in such fractures. However, DHS should be the first choice in Al fractures as the femur-shaft angle is better after DHS treatment, resulting in more convenience functional activity.

Both DHS and PFN-A can be selected in A2 intertrochanteric femur fractures; however, DHS can be preferred in A2 fractures, where stable reduction can be achieved since PFN-A is associated with higher rates of Trendelenburg presence, complication and implant failure, and Hip Harris Score is lower after union. PFN-A should be the choice of the implant in A2 intertrochanteric femur fractures, but DHS can provide successful clinical outcomes in selected patients if a proper 
reduction is provided and implantation techniques are followed meticulously.

We think that femur neck-shaft angle $<128$ degrees should not be accepted during surgery since it is associated with increased complication rates.

Ethics Committee Approval: Approved by the local ethics committee.

Peer-review: Internally peer-reviewed.

Authorship Contributions: Concept: H.F.S., B.D., M.Ç.; Design: H.F.S., B.D., M.Ç.; Supervision: H.F.S., B.D., M.Ç.; Fundings: H.F.S., B.D., M.Ç.; Materials: H.F.S., B.D., M.Ç., B.O., S.D.; Data: H.F.S., B.D., M.Ç., I.D.C., B.O., S.D.; Analysis: H.F.S., B.D., M.Ç., S.D.; Literature search: H.F.S., B.D., M.Ç., I.D.C., B.O., S.D.; Writing: H.F.S., M.Ç., B.D., S.D.; Critical revision: H.F.S., B.D., S.D.

\section{Conflict of Interest: None declared.}

Financial Disclosure: The authors declared that this study has received no financial support.

\section{REFERENCES}

1. Koval KJ, Chen AL, Aharonoff GB, Egol KA, Zuckerman JD. Clinical pathway for hip fractures in the elderly: the Hospital for Joint Diseases experience. Clin Orthop Relat Res 2004;425:72-81. [CrossRef]

2. Siegmeth AW, Gurusamy K, Parker MJ. Delay to surgery prolongs hospital stay in patients with fractures of the proximal femur. J Bone Joint Surg Br 2005;87:112-36. [CrossRef]

3. Dodds SD, Baumgaertner MR. The sliding hip screw. Curr Opin Orthop 2004;15:12-7. [CrossRef]

4. Baumgaertner MR, Curtin SL, Lindskog DM. Intramedullary versus extramedullary fixation for the treatment of intertrochanteric hip fractures. Clin Orthop Relat Res 1998;348:87-94. [CrossRef]

5. Baumgaertner MR, Curtin SL, Lindskog DM, Keggi JM. The value of the tip-apex distance in predicting failure of fixation of peritrochanteric fractures of the hip. J Bone Joint Surg Am 1995;77:1058-64. [CrossRef]

6. Hardy DC, Descamps PY, Krallis P, Fabeck L, Smets P, Bertens CL, et al. Use of an intramedullary hip-screw compared with a compression hip-screw with a plate for intertrochanteric femoral fractures. A prospective, randomized study of one hundred patients. J Bone Joint Surg Am 1998;80:618-30. [CrossRef]

7. Kenzora JE, McCarthy RE, Lowell JD, Sledge CB. Hip fracture mortality. Relation to age, treatment, preoperative illness, time of surgery, and complications. Clin Orthop Relat Res 1984;186:45-56. [CrossRef]

8. Parker MJ, Handoll HH. Gamma and other cephalocondylic intramedullary nails versus extramedullary implants for extracapsular hip fractures in adults. Cochrane Database Syst Rev 2008;3:CD000093. [CrossRef]

9. Anglen JO, Weinstein JN; American Board of Orthopaedic Surgery Research Committee. Nail or plate fixation of intertrochanteric hip fractures: changing pattern of practice. A review of the American Board of Orthopaedic Surgery Database. J Bone Joint Surg Am 2008;90:700-7.

10. Bellabarba C, Herscovici D Jr, Ricci WM. Percutaneous treatment of peritrochanteric fractures using the Gamma nail. Clin Orthop Relat Res 2000;375:30-42. [CrossRef]

11. Saudan M, Lübbeke A, Sadowski C, Riand N, Stern R, Hoffmeyer P. Pertrochanteric fractures: is there an advantage to an intramedullary nail?: a randomized, prospective study of 206 patients comparing the dynamic hip screw and proximal femoral nail.J Orthop Trauma 2002;16:386-93. 12. Papasimos S, Koutsojannis CM, Panagopoulos A, Megas P, Lambiris E. A randomised comparison of AMBI, TGN and PFN for treatment of unstable trochanteric fractures. Arch Orthop Trauma Surg 2005;125:462-8. [CrossRef]

13. Kyle RF, Gustilo RB, Premer RF. Analysis of six hundred and twenty-two intertrochanteric hip fractures. J Bone Joint Surg Am 1979;61:216-21.

14. Zuckerman JD. Hip fracture. N Engl J Med 1996;334:1519-25.

15. Browner B, Levine A, Jüpiter J, Trafton P, Krettek C. Skeletal Trauma. 2 Vol. WB Saunders Company, 1996.

16. Jones HW, Johnston P, Parker M. Are short femoral nails superior to the sliding hip screw? A meta-analysis of 24 studies involving 3,279 fractures. Int Orthop 2006;30:69-78. [CrossRef]

17. Larsson S. Treatment of osteoporotic fractures. Scand J Surg 2002;91:140-6. [CrossRef]

18. Davis TR, Sher JL, Horsman A, Simpson M, Porter BB, Checketts RG. Intertrochanteric femoral fractures. Mechanical failure after internal fixation. J Bone Joint Surg Br 1990;72:26-31. [CrossRef]

19. Şahin S, Ertürer E, Oztürk I, Toker S, Seçkin F, Akman S. Stabil olmayan intertrokanterik femur kırıklarının tedavisinde proksimal femoral çivi antirotasyon osteosentezinin radyografik ve fonksiyonel sonuçları Acta Orthop Traumatol Turc 2010;44:127-34.

20. Ertürer E, Sönmez M, Sarı S, Seçkin F, Kara A, Öztürk İ. Yaşlı hastalarda intertrokanterik kalça kırıklarında Profin ${ }^{\circledR}$ çivisi ile intramedüller osteosentez. Acta Orthop Traumatol Turc 2012;46:107-12. [CrossRef]

21. Boyd HB, Anderson LD. Management of Unstable Trochanteric Fractures. Surg Gynecol Obstet 1961;112:633-8.

22. Baumgaertner MR, Solberg BD. Awareness of tip-apex distance reduces failure of fixation of trochanteric fractures of the hip. J Bone Joint Surg Br 1997;79:969-71. [CrossRef]

23. Ahrengart L, Törnkvist H, Fornander P, Thorngren KG, Pasanen L, Wahlström P, et al. A randomized study of the compression hip screw and Gamma nail in 426 fractures. Clin Orthop Relat Res 2002;401:209-22.

24. Barton TM, Gleeson R, Topliss C, Greenwood R, Harries WJ, Chesser TJ. A comparison of the long gamma nail with the sliding hip screw for the treatment of AO/OTA 31-A2 fractures of the proximal part of the femur: a prospective randomized trial. J Bone Joint Surg Am 2010;92:792-8. [CrossRef]

25. Habernek H, Wallner T, Aschauer E, Schmid L. Comparison of ender nails, dynamic hip screws, and Gamma nails in the treatment of peritrochanteric femoral fractures. Orthopedics 2000;23:121-7.

26. Jaworski JM, Gaździk TS, Kaleta M, Dec J, Godula R. Treatment of trochanteric fractures of the femur: DHS or Gamma nail? - own experience. Ortop Traumatol Rehabil 2003;5:53-9.

27. Utrilla AL, Reig JS, Muñoz FM, Tufanisco CB. Trochanteric gamma nail and compression hip screw for trochanteric fractures: a randomized, prospective, comparative study in 210 elderly patients with a new design of the gamma nail. J Orthop Trauma 2005;19:229-33. [CrossRef]

28. Xu YZ, Geng DC, Mao HQ, Zhu XS, Yang HL. A comparison of the proximal femoral nail antirotation device and dynamic hip screw in the treatment of unstable pertrochanteric fracture. J Int Med Res 2010;38:1266-75. [CrossRef]

29. Kristek D, Lovrić I, Kristek J, Biljan M, Kristek G, Sakić K. The proximal femoral nail antirotation (PFNA) in the treatment of proximal femoral fractures. Coll Antropol 2010;34:937-40.

30. Pajarinen J, Lindahl J, Michelsson O, Savolainen V, Hirvensalo E. Pertrochanteric femoral fractures treated with a dynamic hip screw or a proximal femoral nail. A randomised study comparing post-operative rehabilitation. J Bone Joint Surg Br 2005;87:76-81. [CrossRef] 
ORİJINAL ÇALIŞMA - ÖZET

\section{A1 ve A2 tipi femur intertrokanterik kırıklarında kayan kalça vidası ve proksimal femur çivisi-antirotasyon ile tespit sonrası hastaların fonksiyonel sonuçlarının karşılaştırılması \\ Dr. Hüseyin Fatih Sevinç, ${ }^{1}$ Dr. Meriç Çırpar, ${ }^{2}$ Dr. İbrahim Deniz Canbeyli, ${ }^{2}$ \\ Dr. Bülent Dağlar, ${ }^{3}$ Dr. Birhan Oktaş, ${ }^{2}$ Dr. Serhat Durusoy ${ }^{4}$}

${ }^{1}$ Nevşehir Devlet Hastanesi, Ortopedi ve Travmatoloji Kliniği, Nevşehir

${ }^{2}$ Kırıkkale Üniversitesi Tıp Fakültesi, Ortopedi ve Travmatoloji Anabilim Dalı, Kırıkkale

${ }^{3}$ Güven Hastanesi, Ortopedi ve Travmatoloji Kliniği, Ankara

${ }^{4}$ Bozok Üniversitesi Tıp Fakültesi, Ortopedi ve Travmatoloji Anabilim Dalı, Yozgat

AMAÇ: Dinamik hip screw (DHS) ve proksimal femoral çivi-antirotasyonu (PFN-A) implantları ile tedavi edilen hastaların klinik ve fonksiyonel sonuçlarını karşılaştırmayı amaçladık.

GEREÇ VE YÖNTEM: Çalışmaya Kırıkkale Üniversitesi Tıp Fakültesi Ortopedi ve Travmatoloji Anabilim Dalı’nda femur intertrokanterik kırı̆̆ı nedeniyle DHS ve PFN-A kullanılarak ameliyat edilen, en az 12 ay takibi olan 66'sı erkek, 56'sı kadın olan toplam I 22 hasta alındı. Hastaların erken postoperatif grafilerinde kırığın redüksiyonu değerlendirilmesi, boyun cisim açısı ve tip apeks mesafesi ölçümleri yapıldı. Postoperatif I. ay, 3. ay, 6. ay, I2. ay yapılan takiplerinde kalça eklem hareket açıklığı, uyluk-kalça ağrısı, Trendelenburg pozitifliği bakıldı ve takiplerdeki ve kaynama sonrası çekilen grafilerinde redüksiyon, fiksasyon kaybı, boyun cisim açısı ve tip apeks mesafesi ölçümleri yapıldı. Hastalar kaynama sonrası dönemde Kalça Harris Skoru ile değerlendirildi.

BULGULAR: Kullanılan implanttan bağımsız olarak implant yetmezliği görülen grupta erken postoperatif ölçülen tip apeks mesafesi ortalaması 27.6 iken implant yetmezliği görülmeyen grupta 21,6 idi ve istatistiksel olarak anlamlı bir fark saptandı. Kullanılan implanttan bağımsız olarak implant yetersizliği görülen grupta erken postoperatif ölçülen boyun cisim açısı ortalaması I 23 iken implant yetersizliği görülmeyen grupta I 30 idi ve istatistiksel olarak anlamlı bir fark saptandı. İmplant yetersizliği görülen hastaların tümünde erken postoperatif ölçülen boyun cisim açısının I 28 derecenin altında olduğu saptandı. İmplant yetersizliği görülmeyen hastaların \%94'ünün erken postoperatif ölçülen boyun cisim açısının I28 derecenin üstünde olduğu saptandı.

TARTIŞMA: İmplant yetersizliği olan hastaların tümünde erken postoperatif boyun cisim açısının $128^{\circ}$ altında olması ve implant yetersizliği görülmeyen hastaların \%94'ünde erken postoperatif boyun cisim açısının $128^{\circ}$ ve üzerinde olması cerrahi sırasında bu açının anatomik şekilde restore edilmesinin önemini ortaya çıkarmaktadır. İmplant yetersizliği görülen grupta TAD’nin ortalama $27.5 \mathrm{~mm}$ ve implant yetersizliği görülmeyen grupta ortalama 21.7 olması, bu sistemlerin implantasyonunda tedavi başarısı açısından tekniğin en az seçilen implant türü kadar önemli olduğunu göstermektedir.

Anahtar sözcükler: Dinamik kalça vidası; femur boyun cisim açıs;; femur intertrokanterik kırık; proksimal femoral çivi antirotasyon; tip apeks mesafesi.

Ulus Travma Acil Cerrahi Derg 2020;26(5):81 I-817 doi: 10.14744/tjtes.2020.39888 